\title{
Cytotoxic Anthraquinones from the Stems of Rubia wallichiana DECNE
}

\author{
Tian-Shung Wu, ${ }^{*, a}$ Dau-Min Lin, ${ }^{a}$ Li-Shian SHI, ${ }^{a}$ Amooru Gangaiah DAmu, ${ }^{a}$ Ping-Chung Kuo, ${ }^{a}$ and \\ Yao-Hau Kuo ${ }^{b}$ \\ ${ }^{a}$ Department of Chemistry, National Cheng Kung University; Tainan, Taiwan: and ${ }^{b}$ National Research Institute of Chinese \\ Medicine; Taipei, Taiwan. Received March 10, 2003; accepted May 12, 2003
}

\begin{abstract}
From the stems of Rubia wallichiana DECNE, thirty-four structurally related compounds were isolated and identified. Three of them, namely rubiawallin-A (1), -B (2), and -C (3), constitute the first report of their occurrence from the natural source. Their structures were determined by comprehensive analyses of their 1D and 2D NMR, and electron impact (EI) mass spectral data. Furthermore, an in vitro screening of cytotoxicity of the isolated compounds was also evaluated. Among the testing compounds, 1-hydroxy-2-hydroxymethyl-3-methoxyanthraquinone (4) demonstrated most effective cytotoxicity towards Hepa-3B and Colo-205 cells.
\end{abstract}

Key words rubiawallin; traditional Chinese medicine; tumor cell lines; antiproliferative

Anthraquinones are a class of natural products encompassing several hundreds of compounds, differing in the nature and positions of the substituents. ${ }^{1-3)}$ They are found in a large number of plant families. They are particularly widespread in the subclass Asteridae, comprising among others the plant families Rubiaceae, Gesneriaceae, and Scrophulariaceae. Anthraquinones are not only common constituents of plants of the Rubiaceae, but also of their tissue and cell cultures. $\left.{ }^{4}-7\right)$

In the course of phytochemical studies of medicinal plants from the Chinese traditional medicine, we have investigated Rubia wallichiana DECNE (Rubiaceae), a plant distributed widely in the Himalayan region and northeast India. In clinical biological experiments, plants of the genus Rubia showed antibacteria, anticancer, anticough and antiplatelet aggregation activities. They have also been used to enhance the number of leukocytes, and in the therapy of myocardial infraction. ${ }^{8}$ Phytochemical studies previously performed on the genus, Rubia have led to the isolation of anthraquinones, naphthaquinones, naphthahydroquinones, cyclic hexapeptides, flavonoids, coumarins, iridoids, lignans, triterpenoids, and benzenoids. The present paper deals with the isolation, structural elucidation of three anthraquinones, besides thirtyone known compounds. The in vitro cytotoxicity of the quinonoids isolated was also assessed, taking into account that anthraquinones have been reported to exhibit strong antiproliferative properties on mammalian cells.

\section{Results and Discussion}

Dried and powdered stems of $R$. wallichiana were extracted with methanol. The residue obtained after evaporation of the solvent was fractionated with chloroform and water, followed by conventional purification procedures resulted in the isolation of thirty-four constituents, including three new anthraquinones.

Rubiawallin-A (1) was obtained as yellow needles, mp $>280^{\circ} \mathrm{C}$. The molecular ion peak at $\mathrm{m} / \mathrm{z} 284.0688$ in its high resolution electron impact (HR-EI)-MS was in accordance with the molecular formula $\mathrm{C}_{16} \mathrm{H}_{12} \mathrm{O}_{5}$, deduced also by ${ }^{13} \mathrm{C}$ NMR and distortionless enhancement by polarization transfer (DEPT) analyses. The UV spectrum of 1 exhibited absorption maxima at $225,270,292(\mathrm{sh})$ and $418 \mathrm{~nm}$, suggested an anthraquinone as the basic structure, ${ }^{9)}$ with a single peri-hydroxyl group. It was further supported by a $\mathrm{D}_{2} \mathrm{O}$ ex- changeable singlet at $\delta 13.20$ in ${ }^{1} \mathrm{H}-\mathrm{NMR}$ spectrum and an IR absorption at $3524 \mathrm{~cm}^{-1}$. The IR absorption bands at 1640 and $1600 \mathrm{~cm}^{-1}$ also indicated the presence of free carbonyl and chelated carbonyl groups, respectively. Two carbonyl groups of an anthraquinone skeleton were also found in ${ }^{13} \mathrm{C}$ NMR at $\delta 181.6$ and 188.7 for the nonchelated one and chelated one, respectively. In ${ }^{1} \mathrm{H}-\mathrm{NMR}$ spectrum, a set of ABX protons at $\delta 7.25(1 \mathrm{H}, \mathrm{dd}, J=8.8,2.4 \mathrm{~Hz}), 7.73(1 \mathrm{H}, \mathrm{d}$, $J=2.4 \mathrm{~Hz})$, and $8.26(1 \mathrm{H}, \mathrm{d}, J=8.8 \mathrm{~Hz})$, were assigned to $\mathrm{H}-$ 7, H-5, and H-8 of monosubstituted A-ring, respectively. Two ortho coupled protons at $\delta 7.15(1 \mathrm{H}, \mathrm{d}, J=8.4 \mathrm{~Hz}, \mathrm{H}-3)$ and $7.86(1 \mathrm{H}, \mathrm{d}, J=8.4 \mathrm{~Hz}, \mathrm{H}-4)$, and two methoxyl groups at $\delta$ $4.00\left(3 \mathrm{H}, \mathrm{s}, 6-\mathrm{OCH}_{3}\right)$ and $4.02\left(3 \mathrm{H}, \mathrm{s}, 2-\mathrm{OCH}_{3}\right)$ were also observed. The heteronuclear multiple bond coherence (HMBC) spectrum confirmed the attachment of two methoxyl groups to $\mathrm{C}-2$ and $\mathrm{C}-6$ by displaying correlations of the methoxyls to C-6 $(\delta 165.0)$ and C-2 $(\delta 154.3)$, respectively. In final confirmation, nuclear Overhauser effect spectroscopy (NOESY) spectrum exhibited correlations of the methoxyl at $\delta 4.00$ with H-7, and the methoxyl at $\delta 4.02$ with $\mathrm{H}-3$. The identification of $\mathbf{1}$ was also accomplished by the comparison of spectral data with those of reported synthetic sample. ${ }^{10)}$ Thus the structure $\mathbf{1}$ was established for rubiawallin-A.

Rubiawallin-B (2) was isolated as yellow needles, $\mathrm{mp}$ $136-137^{\circ} \mathrm{C}$. Its molecular formula $\mathrm{C}_{16} \mathrm{H}_{12} \mathrm{O}_{4}$ was determined on the basis of HR-EI-MS data. The IR spectrum showed bands at $3400 \mathrm{~cm}^{-1}$ due to chelated hydroxyl function and bands of a free carbonyl at $1630 \mathrm{~cm}^{-1}$ and a chelated one at $1600 \mathrm{~cm}^{-1}$. In the ${ }^{1} \mathrm{H}-\mathrm{NMR}$ spectrum, a downfield singlet at $\delta 13.11$, exchangeable with $\mathrm{D}_{2} \mathrm{O}$, was attributed to chelated C-1 hydroxyl group. It also exhibited signals of a set of ABX protons at $\delta 7.27(1 \mathrm{H}, \mathrm{dd}, J=8.7,2.5 \mathrm{~Hz}), 7.72(1 \mathrm{H}$, $\mathrm{d}, J=2.5 \mathrm{~Hz})$, and $8.24(1 \mathrm{H}, \mathrm{d}, J=8.7 \mathrm{~Hz})$, a set of two mutually coupled protons at $\delta 7.51(1 \mathrm{H}, \mathrm{d}, J=7.3 \mathrm{~Hz})$ and 7.75 $(1 \mathrm{H}, \mathrm{d}, J=7.3 \mathrm{~Hz}$ ), a methyl group at $\delta 2.38$ (s) and a methoxyl group at $\delta 3.99$ (s). In the NOESY spectrum, the methoxyl at $\delta 3.99(3 \mathrm{H}, \mathrm{s})$ had connectivities with a doublet of doublet at $\delta 7.27$ and a meta-coupled doublet at $\delta 7.72$ and methyl at $\delta 2.38\left(3 \mathrm{H}, \mathrm{s}, 2-\mathrm{CH}_{3}\right)$ with $\mathrm{H}-3$ inferred its attachment to C-7 or C-6 and C-2, respectively. The point of attachment of methoxyl group at C-6 was excluded by comparison of spectral data with those of 1-hydroxy-6-methoxy2-methyl anthraquinone, ${ }^{11)}$ since they differed in chemical 

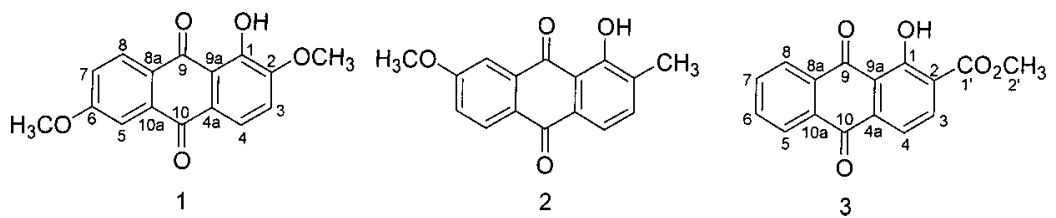

Fig. 1. Structures of Rubiawallin $A-C(1-3)$

shift values of methoxyl and protons of A-ring. Thus, the structure 2 was assigned as rubiawallin-B.

Rubiawallin-C (3) was obtained as yellow needles, mp $136-137^{\circ} \mathrm{C}$. Its HR-EI-MS spectrum with a molecular ion peak at $\mathrm{m} / \mathrm{z} 282.0525$ established the molecular formula $\mathrm{C}_{16} \mathrm{H}_{10} \mathrm{O}_{5}$. The 9,10-anthraquinone chromophore with a perihydroxyl group was evident from its UV absorption maxima at 252, $282(\mathrm{sh}), 327,402 \mathrm{~nm}$. IR spectrum displayed bands for chelated hydroxyl $\left(3400 \mathrm{~cm}^{-1}\right)$, chelated carbonyl $\left(1630 \mathrm{~cm}^{-1}\right)$, a nonchelated carbonyl $\left(1680 \mathrm{~cm}^{-1}\right)$, in addition to an ester carbonyl $\left(1598 \mathrm{~cm}^{-1}\right)$. A chelated hydroxyl at $\delta 13.60$ was located at the peri-position to the C-9 carbonyl group. In the aromatic region, the ${ }^{1} \mathrm{H}-\mathrm{NMR}$ spectrum showed two multiplets for four symmetrical $\mathrm{AA}^{\prime}$ and $\mathrm{BB}^{\prime}$ type of aromatic protons at $\delta 8.31$ and 7.85 , and a pair of doublets at $\delta 8.26(J=7.4 \mathrm{~Hz})$ and $7.85(J=7.4 \mathrm{~Hz})$ indicated that anthraquinone possessing an unsubstituted A-ring and a disubstituted C-ring, respectively. A methoxyl singlet at $\delta 3.99$ combined with an IR absorption at $1598 \mathrm{~cm}^{-1}$ suggested the presence of $-\mathrm{COOCH}_{3}$ group in 3 . It was confirmed by the fragment ion $\left[\mathrm{M}-\mathrm{COOCH}_{3}\right]^{+}$at $m / z 222$ in its EI-MS spectrum. The attachment of $-\mathrm{COOCH}_{3}$ group to $\mathrm{C}-2$ was determined by the downfield shift of $\mathrm{H}-3$ to $\delta 8.26$ due to anisotropic effect of carboxyl group. All these assignments were strongly supported by the NOEs: H-5/H-6, H-6/H-7, H$7 / \mathrm{H}-8, \mathrm{H}-4 / \mathrm{H}-3$, and $\mathrm{H}-3 / 2^{\prime}-\mathrm{CH}_{3}$ in NOESY spectrum. The above spectral analysis strongly supported the proposed structure 3 for rubiawallin-C.

In addition, 1-hydroxy-2-hydroxymethyl-3-methoxyanthraquinone (4), ${ }^{12}$ alizarin-2-methylether (5), ${ }^{13)}$ lucidin $(6),{ }^{14)}$ lucidin primeveroside (7), ${ }^{14)}$ munjistin methyl ether $(8),{ }^{15)}$ nordamnacanthal (9), ${ }^{16)}$ purpurin (10), ${ }^{16)}$ rubiadin $(\mathbf{1 1}),{ }^{15)}$ rubiadin primeveroside (12), ${ }^{17}$ rubischumin-A $(\mathbf{1 3}),{ }^{18)}$ xanthopurpurin (14), ${ }^{15)}$ 1-hydroxy-3-methoxy-2methylanthraquinone (15), ${ }^{19)}$ 1,3-dimethoxy-2-hydroxyanthraquinone (16), ${ }^{20)}$ 1-hydroxy-2-methylanthraquinone $(\mathbf{1 7}),{ }^{21)}$ 1-hydroxy-2-hydroxymethylanthraquinone (18), ${ }^{20)}$ 2-methyl1,3,6-trihydroxyanthraquinone (19), ${ }^{21)}$ 2-methyl-1,3,6-trihydroxyanthraquinone 3 - $O$ - $\alpha$-L-rhamnosyl- $(1 \rightarrow 2)-\beta$-D-glucoside $(\mathbf{2 0}),{ }^{21)}$ 2-methyl-1,3,6-trihydroxyanthraquinone 3-O$\left(6^{\prime}-O\right.$-acetyl)- $\alpha$-L-rhamnosyl- $(1 \rightarrow 2)-\beta$-D-glucoside $\left.\quad(\mathbf{2 1}),{ }^{21}\right)$ 1-hydroxy-5-methoxy-2-methylanthraquinone $(22),{ }^{22)} 2$-hydroxy-1-methoxyanthraquinone $(\mathbf{2 3}),{ }^{20)} 1$-hydroxy-3-methoxyanthraquinone $(\mathbf{2 4}),{ }^{13)}$ 1,8-dihydroxy-2-methylanthraquinone $(\mathbf{2 5}),{ }^{13)}$ 1,3-dihydroxy-2-methoxymethylanthraquinone (26), ${ }^{15)}$ scopoletin $(\mathbf{2 7}),{ }^{23}$ 6,7-dimethoxycoumarin $(\mathbf{2 8}),{ }^{24)} 7$ hydroxy-6-methoxy-8-(3-methylbut-2-enyl)coumarin (29), ${ }^{25)}$ $(+)$-medioresinol $(\mathbf{3 0}),{ }^{26)}$ ursolic acid $(\mathbf{3 1}),{ }^{27)}$ the mixture of $\beta$-sitosterol (32) and stigmasterol (33), ${ }^{28)}$ and docosanoic acid $(34)^{29)}$ were also isolated from the stems of $R$. wallchi$a n a$. They were identified by the comparison of their spectral data with those in literature.

Furthermore, the compounds isolated from $R$. wallchiana
Table 1. Cytotoxicity $\mathrm{ED}_{50}(\mu \mathrm{g} / \mathrm{ml})$ of Compounds Isolated from the Stems of $R$. wallichiana on Tumor Cell Lines

\begin{tabular}{cllll}
\hline \hline \multirow{2}{*}{ Compounds } & \multicolumn{5}{c}{ Cell lines } \\
\cline { 2 - 5 } & KB & Hepa-3B & Hela & Colo-205 \\
\hline Doxorubicin & 0.12 & 0.14 & 0.11 & 0.10 \\
$\mathbf{4}$ & - & 0.6 & 9.15 & 0.58 \\
$\mathbf{5}$ & - & - & - & - \\
$\mathbf{6}$ & - & - & - & - \\
$\mathbf{1 0}$ & 3.1 & - & - & - \\
$\mathbf{1 1}$ & - & - & - & - \\
$\mathbf{1 3}$ & - & 3.58 & - & - \\
$\mathbf{1 4}$ & 6.57 & 1.7 & - & 1.9 \\
$\mathbf{1 5}$ & - & - & 24.5 & - \\
$\mathbf{1 7}$ & - & - & - & - \\
$\mathbf{1 8}$ & - & 3.85 & 24.5 & - \\
$\mathbf{1 9}$ & - & 1.7 & 12.3 & 1.16 \\
$\mathbf{2 1}$ & - & - & - & - \\
$\mathbf{2 4}$ & - & - & - & - \\
$\mathbf{2 5}$ & - & - & - & - \\
$\mathbf{2 7}$ & - & - & - & - \\
$\mathbf{2 8}$ & - & 7.05 & - & - \\
$\mathbf{3 1}$ & - & - & - & \\
\hline
\end{tabular}

-: $\mathrm{ED}_{50}>25 \mu \mathrm{g} / \mathrm{ml}$.

were screened for their in vitro cytotoxicity against human nasal pharynegeal carcinoma (KB), human hepatoma (Hepa3B), human cervix epithelioid carcinoma (Hela) and human colon carcinoma (Colo-205) tumor cell lines, and doxorubicin was used as reference compound. The results $\left(\mathrm{ED}_{50}\right.$ values) of the cytotoxicity assay were summarized in Table 1. All the tested anthraquinones showed different degrees of activity with, 4 being the most potent one against Hepa-3B and Colo-205 cell lines. On the other hand, 14 and 19 also exhibited marked cytotoxicity against Hepa-3B and Colo-205 cell lines. 10 and 14; and 13 and 18 are only moderately active against KB and Hepa-3B cell lines, respectively.

\section{Experimental}

General Experimental Methods Melting points were uncorrected. ${ }^{1} \mathrm{H}-$ and ${ }^{13} \mathrm{C}$-NMR spectra were obtained on the Bruker AC-200, AMX-400 and Varian-400 Unity Plus NMR spectrometers, with tetramethylsilane (TMS) as internal standard. IR spectra were determined as $\mathrm{KBr}$ discs, and UV spectra were recorded in $\mathrm{MeOH}$. EI and $\mathrm{HR}$-EI-MS were measured with a $70 \mathrm{eV}$ direct inlet system on a VG70-250S spectrometer. Optical rotations were recorded on a Jasco DIP-370 digital polarimeter.

Plant Material The stems of $R$. wallichiana used in this study were collected in Tibet, China Mainland, on July, 1996, and authenticated by Prof. C. S. Kuoh. A voucher specimen (TSWu 1996020) has been deposited at the Herbarium of National Cheng Kung University, Tainan, Taiwan.

Extraction and Separation The air-dried stems $(4.2 \mathrm{~kg})$ were cut into small pieces, extracted with $\mathrm{MeOH}(61 \times 10)$, and concentrated to give a deep brown syrup $(750 \mathrm{~g})$. The crude extract was partitioned with $\mathrm{H}_{2} \mathrm{O}$ and $\mathrm{CHCl}_{3}$, successively. The $\mathrm{CHCl}_{3}$ layer was concentrated in vacuo to leave a brown syrup. The residue was chromatographed on silica gel column and eluted with a gradient of $\mathrm{C}_{6} \mathrm{H}_{6}$ and $\left(\mathrm{CH}_{3}\right)_{2} \mathrm{CO}$ to give ten fractions. Fraction 3 was rechromatographed with silica gel column using $\mathrm{CHCl}_{3}$-hexane $(1: 5)$ 
as an eluent to obtain $\mathbf{2 5}(4.4 \mathrm{mg})$, and $\mathbf{3 4}(2.6 \mathrm{mg})$. Fraction 4 was repeatedly column chromatographed over silica gel and eluted with $\mathrm{CHCl}_{3}$ : hexane $(1: 1)$ to give $\mathbf{2}(1.2 \mathrm{mg}), \mathbf{1 0}(34.6 \mathrm{mg}), \mathbf{1 5}(10.3 \mathrm{mg})$ and $\mathbf{2 2}(0.3 \mathrm{mg})$, successively. Fraction 6 was rechromatographed on a silica gel column and eluted with a gradient of $\mathrm{CHCl}_{3}$ and $\left(\mathrm{CH}_{3}\right)_{2} \mathrm{CO}$ to obtain $3(1.2 \mathrm{mg}), \mathbf{1 3}$ $(43.0 \mathrm{mg})$ and $24(1.0 \mathrm{mg})$. Fraction 7 was rechromatographed on a silica gel column and eluted with $\mathrm{CHCl}_{3}:\left(\mathrm{CH}_{3}\right)_{2} \mathrm{CO}(10: 1)$ to give $5(7.9 \mathrm{mg})$, $6(74.5 \mathrm{mg}), \mathbf{1 1}(758.0 \mathrm{mg}), \mathbf{1 3}(1.1 \mathrm{mg})$ and $\mathbf{1 5}(15.4 \mathrm{mg})$. Fraction 7 was rechromatographed on a silica gel column and eluted with $\mathrm{CHCl}_{3}:\left(\mathrm{CH}_{3}\right)_{2} \mathrm{CO}(5: 1)$ to afford $28(6.8 \mathrm{mg})$ and $\mathbf{3 1}(1.3 \mathrm{mg})$. Fraction 9 was also rechromatographed on silica gel column and eluted with $\mathrm{CHCl}_{3}:\left(\mathrm{CH}_{3}\right)_{2} \mathrm{CO}(3: 1)$ to give $8(2.0 \mathrm{mg})$ and $27(71.5 \mathrm{mg})$. Fraction 10 was chromatographed on silica gel column and eluted with $\mathrm{CHCl}_{3}:\left(\mathrm{CH}_{3}\right)_{2} \mathrm{CO}(1: 1)$ to obtain $\mathbf{1 4}(15.0 \mathrm{mg}), \mathbf{1 8}(1.8 \mathrm{mg}), \mathbf{1 9}(2.5 \mathrm{mg}), \mathbf{2 3}$ (2.1 $\mathrm{mg}), \mathbf{2 9}(2.3 \mathrm{mg})$, and mixture of $\mathbf{3 2}$ and $\mathbf{3 3}(7.2 \mathrm{mg})$, successively. Fraction 13 was rechromatographed on a silica gel column and eluted with $\mathrm{CHCl}_{3}:\left(\mathrm{CH}_{3}\right)_{2} \mathrm{CO}(1: 2)$ to obtain $\mathbf{1}(2.5 \mathrm{mg}), \mathbf{4}(3.0 \mathrm{mg})$ and $\mathbf{1 6}(16.0 \mathrm{mg})$, respectively. Fraction 14 and 15 was rechromatographed on a silica gel column and eluted with $\mathrm{CHCl}_{3}:\left(\mathrm{CH}_{3}\right)_{2} \mathrm{CO}(1: 5)$ to afford $\mathbf{3 0}(7.8 \mathrm{mg})$.

The water layer was directly chromatographed on Diaion HP-20 column and eluted with a gradient of $\mathrm{H}_{2} \mathrm{O}$ and $\mathrm{MeOH}$ to give 9 fractions. Fraction 6 was rechromatographed on RP-18 column and eluted with a gradient of $\mathrm{H}_{2} \mathrm{O}$ and $\mathrm{MeOH}$ to give $7(146.0 \mathrm{mg}), \mathbf{1 2}(73.7 \mathrm{mg})$ and $26(1.7 \mathrm{mg})$. Fraction 7 was rechromatographed on a silica gel column and eluted with $\mathrm{CHCl}_{3}: \mathrm{MeOH}(1: 20)$ to obtain $20(1.0 \mathrm{mg})$. Fraction 8 and 9 was treated in the similar method as fraction 7 to afford $21(32.0 \mathrm{mg})$.

Rubiawallin-A (1): Red needles (acetone); $\mathrm{mp}>280{ }^{\circ} \mathrm{C} .{ }^{1} \mathrm{H}-\mathrm{NMR}\left(\mathrm{CDCl}_{3}\right.$, $400 \mathrm{MHz}) \delta 4.00\left(3 \mathrm{H}, \mathrm{s}, 6-\mathrm{OCH}_{3}\right), 4.02\left(3 \mathrm{H}, \mathrm{s}, 2-\mathrm{OCH}_{3}\right), 7.15(1 \mathrm{H}, \mathrm{d}$, $J=8.4 \mathrm{~Hz}, \mathrm{H}-3), 7.25(1 \mathrm{H}, \mathrm{dd}, J=8.8,2.4 \mathrm{~Hz}, \mathrm{H}-7), 7.73(1 \mathrm{H}, \mathrm{d}, J=2.4 \mathrm{~Hz}$, $\mathrm{H}-5), 7.86(1 \mathrm{H}, \mathrm{d}, J=8.4 \mathrm{~Hz}, \mathrm{H}-4), 8.26(1 \mathrm{H}, \mathrm{d}, J=8.8 \mathrm{~Hz}, \mathrm{H}-8), 13.20(1 \mathrm{H}$, $\mathrm{s}, \mathrm{D}_{2} \mathrm{O}$ exchangeable, $\left.\mathrm{OH}\right) .{ }^{13} \mathrm{C}-\mathrm{NMR}\left(\mathrm{CDCl}_{3}, 100 \mathrm{MHz}\right) \delta 55.6\left(6-\mathrm{OCH}_{3}\right)$, $57.1\left(5-\mathrm{OCH}_{3}\right), 109.8(\mathrm{C}-5), 115.0(\mathrm{C}-3), 115.5$ (C-9a), 120.3 (C-7), 121.0 (C-4), 125.5 (C-4a), 126.8 (C-8a), 128.9 (C-8), 136.4 (C-10a), 152.7 (C-1), 154.3 (C-2), 165.0 (C-6), 181.6 (C-10), 188.7 (C-9). IR (KBr) cm ${ }^{-1}: 1640$, 1550. UV $\lambda_{\max }(\mathrm{MeOH}) \mathrm{nm}(\log \varepsilon): 418$ (5.12), 292 (4.37), 270 (4.33), 225 (4.21). HR-EI-MS $m / z$ : 284.0688 (Calcd for $\mathrm{C}_{16} \mathrm{H}_{12} \mathrm{O}_{5}: 284.0684$ ). EI-MS $m / z: 284\left(\mathrm{M}^{+}\right), 255,241$.

Rubiawallin-B (2): Yellow needles (acetone); mp 136-137 ${ }^{\circ} \mathrm{C} .{ }^{1} \mathrm{H}-\mathrm{NMR}$ $\left(\mathrm{CDCl}_{3}, 200 \mathrm{MHz}\right) \delta: 2.38\left(3 \mathrm{H}, \mathrm{s}, 2-\mathrm{CH}_{3}\right), 3.99\left(3 \mathrm{H}, \mathrm{s}, 7-\mathrm{OCH}_{3}\right), 7.27(1 \mathrm{H}$, dd, $J=8.7,2.3 \mathrm{~Hz}, \mathrm{H}-6), 7.51(1 \mathrm{H}, \mathrm{d}, J=7.3 \mathrm{~Hz}, \mathrm{H}-3), 7.72(1 \mathrm{H}, \mathrm{d}$, $J=2.3 \mathrm{~Hz}, \mathrm{H}-8), 7.75(1 \mathrm{H}, \mathrm{d}, J=7.3 \mathrm{~Hz}, \mathrm{H}-4), 8.25(1 \mathrm{H}, \mathrm{d}, J=8.7 \mathrm{~Hz}, \mathrm{H}-5)$, $13.11\left(1 \mathrm{H}, \mathrm{s}, \mathrm{D}_{2} \mathrm{O}\right.$ exchangeable, OH). IR $(\mathrm{KBr}) \mathrm{cm}^{-1}: 3400,1630,1600$. UV $\lambda_{\max }(\mathrm{MeOH}) \mathrm{nm}(\log \varepsilon)$ : 411 (5.12), 334 (4.98), 292 (4.21), 261 (4.18). HR-EI-MS $m / z: 268.0733$ (Calcd for $\mathrm{C}_{16} \mathrm{H}_{12} \mathrm{O}_{4}: 268.0736$ ). EI-MS $m / z: 268$ $\left(\mathrm{M}^{+}\right), 253,251,239,225,222,181,165,152,139,115$.

Rubiawallin-C (3): Yellow needles (acetone); mp 136-137 ${ }^{\circ} \mathrm{C} .{ }^{1} \mathrm{H}-\mathrm{NMR}$ $\left(\mathrm{CDCl}_{3}, 200 \mathrm{MHz}\right) \delta: 3.99\left(3 \mathrm{H}, 2^{\prime}-\mathrm{CH}_{3}\right), 7.85(1 \mathrm{H}, \mathrm{d}, J=7.4 \mathrm{~Hz}, \mathrm{H}-3), 7.85$ $(2 \mathrm{H}, \mathrm{m}, \mathrm{H}-6,7), 8.26(1 \mathrm{H}, \mathrm{d}, J=7.4 \mathrm{~Hz}, \mathrm{H}-4), 8.31(2 \mathrm{H}, \mathrm{m}, \mathrm{H}-5,8), 13.60$ $\left(1 \mathrm{H}, \mathrm{s}, \mathrm{D}_{2} \mathrm{O}\right.$ exchangeable, OH). IR $(\mathrm{KBr}) \mathrm{cm}^{-1} 1680,1630,1510$. UV $\lambda_{\max }$ $(\mathrm{MeOH}) \mathrm{nm}(\log \varepsilon): 402$ (4.15), 327 (4.06), 282 (3.95, sh), 252 (3.90). HREI-MS $m / z: 282.0525$ (Calcd for $\mathrm{C}_{16} \mathrm{H}_{10} \mathrm{O}_{5}: 282.0528$ ). EI-MS $m / z: 282$ $\left(\mathrm{M}^{+}\right), 250,222$.

Biological Assay The in vitro cytotoxicity assay against KB (nasal pharnegeal carcinoma), Hepa-3B (hepatoma), Hela (cervix carcinoma), and COLO-205 (colon carcinoma) tumor cells by the methylene blue dying method was based on reported procedures. ${ }^{30-33)}$ The cells for bioassay were cultured in RPMI- 1640 medium supplemented with a $5 \% \mathrm{CO}_{2}$ incubator at $37^{\circ} \mathrm{C}$. In summary, the assay depends on binding the methylene blue to the fixed monolayer at $\mathrm{pH} 8.5$ and, after washing the monolayer, releasing dye by lowering the $\mathrm{pH}$. Entries and control standard agents were prepared at concentrations of $1,10,40$, and $100 \mu \mathrm{g} / \mathrm{ml}$. The detailed procedures of this experiment are in previous report. ${ }^{33)}$ Finally, the 96-well tray was dipped into a $0.01 \mathrm{~m}$ borated-buff solution four times for the removing the dye. Then, $100 \mu \mathrm{l} /$ well ethanol- $0.1 \mathrm{M} \mathrm{HCl}(1 / 1 \mathrm{v} / \mathrm{v})$ was measured on a microtiter plate reader (Dynatech, MR 7000) at wavelength of $650 \mathrm{~nm}$. As of the $\mathrm{ED}_{50}$ value was defined during a comparison with the untreated cells at the concentration of test sample resulting in $50 \%$ reduction of absorbance.
Acknowledgements The author is grateful for financial support from the National Research Institute of Chinese Medicine and National Science Council, Taiwan, R. O. C.

\section{References}

1) Thomson R. H., "Naturally Occurring Quinones," 2nd ed., Academic Press, London, 1971.

2) Thomson R. H., "Naturally Occurring Quinones. III. Recent Advances," Chapman and Hall, London, 1987.

3) Thomson R. H., "Naturally Occurring Quinones. IV," Chapman and Hall, London, 1996.

4) Mulder-Krieger T., Verpoorte R., de Water A., van Gessel M., van Oeveren B. C. J. A., Svendsen A. B., Planta Med., 46, 19-24 (1982).

5) Wijnsma R., Verpoorte R., Mulder-Krieger T., Svendsen A. B., Phytochemistry, 23, 2307-2311 (1984).

6) Robins R. J., Payne J., Rhodes M. J. C., Phytochemistry, 25, 23272334 (1986).

7) Wijnsma R., Go J. T. K. A., Harkes P. A. A., Verpoorte R., Svendsen A. B., Phytochemistry, 25, 1123-1126 (1986).

8) “Chung Hua Ben Zhao," Vol. II, ed. by Editorial Committee of National Bureau of Chinese Medicine, Shanghai Science and Technology Books, Beijing, 1998, p. 1539.

9) Scott A. I., "Interpretation of the Ultraviolet Spectra of Natural Products," Pergamon Press, New York, 1964, p. 286.

10) Graebe vou C., Thode C., Justus Liebigs Ann. Chem., 349, 207-222 (1906).

11) De Silva S. O., Watanbe M., Snieckus V., J. Org. Chem., 44, 48024809 (1979).

12) Briggs L. H., Nicholls G. A., J. Chem. Soc., 1953, 3068-3069 (1953).

13) Savard J., Brassard P., Tetrahedron, 40, 3455-3464 (1984).

14) Inoue K., Nayeshiro H., Inouye H., Zenk M., Phytochemistry, 20, 1693-1700 (1981).

15) Kawasaki Y., Goda Y., Yoshihira K., Chem. Pharm. Bull., 40, 15041509 (1992).

16) Burnett A. R., Thomson R. H., J. Chem. Soc., 1968, 2437-2441 (1968).

17) Hill R., Richter D., J. Chem. Soc., 1936, 1714-1719 (1936).

18) Allevi P., Anastasia M., Fiecchi A., Sanvito A. M., Scala A., Synthesis, 6, 438-440 (1991).

19) Lee H. H., J. Chem. Soc., 1969, 501-503 (1969).

20) Banthorpe D. V., White J. J., Phytochemistry, 38, 107-112 (1995).

21) Itokawa H., Takeya K., Qiao Y. F., Phytochemistry, 28, 3465-3468 (1989).

22) Boisvert L., Brassard P., J. Org. Chem., 53, 4052-4059 (1988).

23) Sibanda S., Ndengu B., Multari G., Pompi V., Galeffi C., Phytochemistry, 28, 1550-1552 (1989).

24) Joseph-Nathan P., Dominguez M., Ortega D. A., J. Heterocycl. Chem., 21, 1141-1144 (1984).

25) Huang S. C., Wu P. L., Wu T. S., Phytochemistry, 44, 179-181 (1997).

26) Deyema T., Ikawa T., Nishibe S., Chem. Pharm. Bull., 33, 3651-3657 (1985).

27) Numata A., Yang P., Takahashi C., Fujiki R., Nabae M., Fujita E., Chem. Pharm. Bull., 37, 648-651 (1989).

28) Wu T. S., Wang M. L., Shyur H. J., Leu Y. L., Chan Y. Y., Teng C. M., Kuo S. C., Chin. Pharm. J., 46, 447-455 (1994).

29) Mendes F. N. P., Silveira E. R., Phytochemistry, 35, 1499-1504 (1994).

30) Elliott W. M., Auersperg N., Biotech. Histochem., 68, 29-35 (1993).

31) Ferguson P. J., Fisher M. H., Stephenson J., Li D. H., Zhou B. D., Cheng Y. C., Cancer Res., 48, 5956-5961 (1988).

32) Chen C. F., Hwang J. M. H., Wu C. H., Chen C. S., Chen K. Y., Chin. Med. J. (Taipei), 46, 7-16 (1990).

33) Kuo Y. H., Kuo, L. M. Y., Chen C. F., J. Org. Chem., 62, 3242-3245 (1997). 